\title{
Accidental Overdose and Improper Vaccination with BCG in Childhood: Report of Three Cases
}

\author{
Çocuklukta BCG ile Kazara Doz Aşımı ve \\ Uygun Olmayan Aşılama: Üç Vakanın Bildirimi
}

Nazan ÇOBANOĞLU, MD, ${ }^{a}$ Uğur ÖZÇELIK, MD, ${ }^{a}$ Ebru YALÇIN, MD, ${ }^{a}$ Deniz DOĞRU, MD, ${ }^{a}$ Mehmet KÖSE, MD, ${ }^{a}$ Sevgi PEKCAN, MD, ${ }^{a}$ Nural KIPER, MDa

aPaediatric Pulmonary Diseases Unit, Hacettepe University

Faculty of Medicine, Ankara

This study was presented at 4th National Congress of Pediatric Breathing Airways Diseases and Cystic Fibrosis.

Geliş Tarihi/Received: 07.05 .2009 Kabul Tarihi/Accepted: 05.12.2009

Yazışma Adresi/Correspondence: Nazan ÇOBANOĞLU, MD

Hacettepe University

Faculty of Medicine,

Paediatric Pulmonary Diseases Unit, Ankara,

TÜRKIYE/TURKEY

nazanc@ hacettepe.edu.tr

doi:10.5336/medsci.2009-13375

Copyright $\odot 2011$ by Türkiye Klinikleri

\begin{abstract}
Tuberculosis is a major health problem worldwide. Vaccination is a main strategy in reducing the transmission rate. Adverse reactions associated with BCG vaccination have been well documented, but events due to accidental overdose and/or improper vaccination are scarce in the literature. We herein report three pediatric cases who were vaccinated improperly with an overdose BCG, developed cold abscesses at the injection sites and were treated with isoniazid only or combined with rifampicin for six months. Physicians and other vaccine providers/administrators should be encouraged to report events of overdose and/or improper administration to constitute a guideline about treatment since there is no consensus regarding treatment of such complications.
\end{abstract}

Key Words: BCG vaccine; overdose

ÖZET Tüberküloz tüm dünyada major bir sağlık problemidir. Aşılama bulaş hızını azaltmakta ana stratejidir. BCG aşısıyla ilişkili advers reaksiyonlar iyi bir biçimde belgelenmiştir ama literatürde kazara doz aşımı ve/veya uygun olmayan aşılamaya bağlı olaylar az sayıdadır. Biz burada aşırı doz BCG ile uygun olmayan biçimde aşılanan, enjeksiyon yerlerinde soğuk abseler gelişen ve ya tek başına izoniazid ile ya da izoniazid ile birlikte rifampisin ile altı ay boyunca tedavi edilen üç pediyatrik vaka bildiriyoruz. Bu tür komplikasyonların tedavisi hakkında bir uzlaşı bulunmadığından hekimler ve aşıları sağlayan/uygulayan diğer kişiler doz aşımı ve/veya uygun olmayan uygulama olaylarını bildirmeye teşvik edilmelidir.

Anahtar Kelimeler: BCG aşısı; aşırı doz

Turkiye Klinikleri J Med Sci 2011;31(3):724-6

T uberculosis, caused by Mycobacterium tuberculosis, is a major health problem worldwide. One third of the world's population is believed to be infected by Mycobacterium tuberculosis. ${ }^{1}$ Preventing the development of tuberculosis by vaccination as well as proper diagnosis and treatment of the disease are main strategies in reducing the transmission rate.

Bacillus Calmette-Guérin (BCG) was developed from Mycobacterium bovis in 1908 and first used in $1921 .{ }^{2}$ It is generally agreed that the vaccine is effective against the disseminating disease and meningoencephalitis. ${ }^{3}$ The vaccine has been administered in a variety of ways in time. It was originally given orally, and subsequently has been administered intradermally (ID) or subcutaneously (SC). ${ }^{2}$ There is a great worldwide experience with 
BCG vaccination, and it is generally considered as a very safe vaccine with few side effects. ${ }^{3}$ Adverse reactions associated with BCG vaccine are more common in younger persons and usually associated with improper technique of administration. ${ }^{4,5} \mathrm{Ho}$ wever, adverse events due to accidental overdose and/or improper vaccination are scarce in the medical literature. We herein report three pediatric cases who were referred to the Pediatric Pulmonary Diseases Unit of Hacettepe University after accidental (intramuscularly $[\mathrm{IM}]$ ) vaccination with an ID preparation of BCG vaccine with overdoses. Informed consents from the parents of the subjects were obtained before reporting the patients.

\section{CASE REPORTS}

\section{CASE 1}

A Human Immunodeficiency Virus (HIV)-negative 4-month-old boy born to a HIV-negative mother was referred because of an accidental vaccination in May 2001. He had been accidentally vaccinated with an ID BCG preparation in a volume $(0.5 \mathrm{ml})$ ten times the recommended dose instead of a diphtheria, pertussis and tetanus vaccine on his left deltoid muscle at two months of age. He was put on isoniazid treatment $(5 \mathrm{mg} / \mathrm{kg} / \mathrm{d})$. Four months later, the patient was admitted for a swelling on his injection site. An erythematous, soft, non-sore and mobile nodule was determined at the middle part of his left deltoid muscle region. Chest roentgenogram was normal. Left deltoid muscle ultrasound (US) revealed a subcutaneous (but seeding partly into the muscle) nonvascularized hypo-echoic lesion with a diameter of 17x12x10 mm. Isoniazid treatment was completed to six months. The nodule disappeared five months after the cessation of the treatment. The patient is currently healthy and 8 years old.

\section{CASE 2}

A HIV-negative 35-day-old boy whose mother was also HIV-negative was referred very soon after an accidental IM vaccination with an ID preparation of BCG vaccine on his left upper leg with an amount of $0.5 \mathrm{ml}$ (ten times the recommended dose) instead of a hepatitis B vaccine in December 2007. His chest $\mathrm{X}$-ray was normal. The patient was prescribed isoniazid and rifampicin $(10 \mathrm{mg} / \mathrm{kg} / \mathrm{d})$ treat- ments. Two months after the vaccination, the patient was admitted for a nodule on his left upper leg. A soft, non-sore, non-erythematous and mobile nodule was palpated. Left upper leg US revealed a non-vascularized hypo-echoic lesion with a diameter of $17 \mathrm{x} 7 \mathrm{~mm}$ in the muscle. At his last visit in February 2009, eight months after completing the treatment period of six months, his physical examination was normal.

\section{CASE 3}

A HIV-negative 24-month-old girl who had been accidentally (IM on her left deltoid muscle) vaccinated with an ID preparation of BCG vaccine with an amount of $0.5 \mathrm{ml}$ (five times the recommended dose) instead of Haemophilus influenzae type B vaccine at two months of age was referred in July 2008. Her mother was also HIV-negative. Her chest roentgenogram was normal. She was put on isoniazid and rifampicin treatments. One month later, her parents noticed a suppurative nodule on her left shoulder and took her to a pediatrician. US revealed a non-vascularized hypo-echoic lesion with a diameter of $33 \mathrm{~mm}$ in her left deltoid muscle, and it was surgically drained for two times by the same doctor. At her last visit in January of 2009 soon after completing a 6-month treatment, her physical examination was unremarkable.

\section{DISCUSSION}

BCG vaccination is followed by a local reaction that resolves without any sequelae. ${ }^{2}$ The development of adverse events is associated with the concentration of bacilli, patient's age (more common in younger subjects), strain, inappropriate application (e.g., given SC instead of ID), and excessive dose (the standard dose is $0.1 \mathrm{ml}$ for children and adults, and $0.05 \mathrm{ml}$ for infants up to 12 months). These adverse events range from slow-healing ulcers, hypertrophy and/or suppuration of satellite lymph nodes and localized abscess to hematogenous dissemination, when applied to a deeper skin layer or to immunocompromised patients. ${ }^{1,6}$

In the English literature there are very few reports about overdose and/or improper application of BCG vaccine, whether to treat these subjects, and which drugs, if any, should be used. 
Puliyel et al. ${ }^{7}$ have reported infants vaccinated intradermally with a percutaneous BCG preparation with a volume approximately five times the recommended dose. They have reported axillary lymphadenopathy, papules and ulcers of $>10 \mathrm{~mm}$ in diameter, abscesses, but not any specific treatment.

El Ouazzani et al. ${ }^{8}$ have reported 12 cases: Three patients received 10 times the recommended dose of BCG and the injection was too deep in nine cases. Six of them had progressive ulceration, granuloma with caseous necrosis, and one case had humeral osteitis and received treatment for six months.

Revaccination with BCG may cause lesions similar to those related with overdose vaccination. In two revaccination studies. ${ }^{9,10}$ ulcers, tuberculosis-like cutaneous lesions, acute cutaneous eruptions, subcutaneous cold and hot abscesses, keloid and lupus-like reaction have been described. They were treated with isoniazid alone or a combination of anti-tuberculosis drugs. ${ }^{10}$

Erkul et al. ${ }^{11}$ have reported five infants revaccinated with a volume five times the recommended dose, and only one of them had a cold abscess.

Recently a 14-year-old girl who was inadvertently immunised with an excessively large dose of BCG vaccine and revealed a subcutaneous fluctuant tender lump at the injection site was reported. ${ }^{12}$ This lump was surgically excised within $12 \mathrm{~h}$ of im- munisation and she was treated with isoniasid and rifampicin for six weeks.

All of the patients in our report were in the infancy period. As it is clear from the previously reported cases referenced in this manuscript that there is no consensus about the choice of treatment and the duration of chemotherapy for the treatment of overdose and/or improper vaccination with BCG, therefore we treated case 1 with isoniazid alone similar to the treatment of latent tuberculous infection, and the other two cases with a combination of isoniazid and rifampicin for six months. The treatment with two anti-tuberculous agents for six months could be considered too much longer for some physicians, but we decided this period of treatment after considering the physiological immune deficiency during infancy. All three patients revealed cold abscesses at the injection sites at presentation, but all healed without any sequelae.

In conclusion, overdose and/or improper administration of BCG vaccine in childhood, both worrisome for the healthcare professionals and parents involved, may result in mild or serious adverse reactions. There is no consensus regarding treatment of these complications. Physicians and other vaccine providers/administrators should be encouraged to report events of overdose and/or improper administration to constitute a consensus about treatment.

\section{REFERENCES}

1. Barreto ML, Pereira SM, Ferreira AA. BCG vaccine: efficacy and indications for vaccination and revaccination. J Pediatr (Rio J) 2006;82(3 Suppl):S45-54.

2. Bellet JS, Prose NS. Skin complications of Bacillus Calmette-Guerin immunization. Curr Opin Infect Dis 2005;18(2):97-100.

3. Goraya JS, Virdi VS. Bacille Calmette-Guerin lymphadenitis. Postgrad Med J 2002;78(920): 327-9.

4. Lotte A, Wasz-Hockert O, Poisson N, Engbaek H, Landmann H, Quast U, et al. Second IUATLD study on complications induced by intradermal BCG vaccination. Bull Int Union Tuberc Lung Dis 1988;63(2):47-59.

5. Talbot EA, Perkins MD, Silva SFM, Frothingham R. Disseminated Bacille Calmette-Guerin disease after vaccination: case report and review. Clin Infect Dis 1997;24(6): 1139-46.

6. Deeks SL, Clark M, Scheifele DW, Law BJ, Dawar M, Ahmadipour N, et al. Serious adverse events associated with Bacille CalmetteGuerin vaccine in Canada. Pediatr Infect Dis J 2005;24(6):538-41.

7. Puliyel JM, Hughes A, Chiswick ML, Mughal MZ. Adverse local reactions from accidental BCG overdose in infants. BMJ 1996;313 (7056):528-9.

8. El Ouazzani H, Lamsyah H, Alioua Z, Rhorfi I, Rguibi M, Ghfir M, et al. Adverse effects of BCG revaccination: 12 cases. Ann Dermatol Venereol 2007;134(2):129-32.

9. Dourado I, Rios MH, Pereira SM, Cunha SS, Ichihara MY, Goes JC, et al. Rates of adverse reactions to first and second doses of BCG vaccination: results of a large community trial in Brazilian school children. Int J Tuberc Lung Dis 2003;7(4):399-402.

10. Cunha AJLA, Sant'Anna CC, Mannarino R, Labanca TC, Ferreira S, March MF. Adverse effects of BCG revaccination: a report on 13 cases from Rio de Janeiro, Brazil. Int J Tuberc Lung Dis 2002;6(12):1110-3.

11. Erkul PE, Yalçın SS, Şirin F. [Infantile BCG revaccination with an inappropriate technique: malpractice: case report]. Turkiye Klinikleri J Pediatr 2007;16(1):62-4.

12. Ritz N, Tebruegge M, Streeton J, Curtis N. Too much of a good thing: management of BCG vaccine overdose. Vaccine 2009;27(41): 5562-4. 